\title{
Regulation of High-affinity IgE Receptor-mediated Mast Cell Activation by Murine Low-affinity IgG Receptors
}

Marc Daëron, Odile Malbec, Sylvain Latour, Michel Arock, ${ }^{\star}$ and Wolf H. Fridman

Laboratoire d'Immunologie Cellulaire et Clinique, INSERM U255, Institut Curie, Paris; and *Laboratoire d'Hématologie, Faculté de Pharmacie de l'Université Paris $V$

\begin{abstract}
Allergic symptoms result from the release of granular and lipidic mediators and of cytokines by inflammatory cells. The whole process is initiated by the aggregation of mast cell and basophil high-affinity IgE receptors (FceRI) by IgE and antigen. We report here that IgE-induced release of mediator and cytokine can be inhibited by cross-linking FceRI to low-affinity IgG receptors (FcyRII) which are constitutively expressed on mast cells and basophils. Using a model of stable transfectants in RBL-2H3 cells expressing endogeneous rat FceRI and recombinant murine FcyRII, we showed that inhibition requires that $F c \in R I$ be crosslinked to FcyRII by the same multivalent ligand. Inhibition of cross-linked receptors left non-cross-linked FceRI capable of triggering mediator release and was reversible upon disengagement. Both isoforms of wild-type FcyRII were equally capable of inhibiting FceRI-mediated mast cell activation provided they had an intact intracytoplasmic domain. Our results demonstrate that mast cell secretory responses triggered by high-affinity receptors for IgE may be controlled by low-affinity receptors for IgG. This regulation of FceRI-mediated mast cell activation is of potential interest in mast cell physiology and in allergic pathology. ( $\mathrm{J}$. Clin. Invest. 1995. 95:577-585.) Key words: Fc $\gamma$ receptors II • Fce receptors $I \cdot$ immune complexes - mediators and cytokines • allergy
\end{abstract}

\section{Introduction}

Allergic manifestations are initiated by the aggregation of highaffinity IgE receptors $(\mathrm{Fc} \in \mathrm{RI})^{1}$ expressed on mast cells and basophils, when Fc $\epsilon$ RI-bound IgE antibodies bind multivalent allergens (1). Fc $\epsilon$ RI are multichain-receptors composed of an

\footnotetext{
Address correspondence to Dr. Marc Daëron, Laboratoire d'Immunologie Cellulaire \& Clinique, INSERM U.255, Institut Curie, 26, rue d'Ulm, 75005 Paris, France. Phone: 1-4432-4220; FAX: 1-4051-0420.

Received for publication 19 May 1994 and in revised form 23 August 1994.
}

1. Abbreviations used in this paper: BCR, B cell receptor; BMMC, bone marrow-derived mast cells; Fc $\epsilon$ RI. high-affinity receptors for the Fc portion of IgE; Fc $\gamma$ RII and III, murine type II and III low-affinity receptors for the Fc portion of IgG; IC, intracytoplasmic; MAR, mouse anti-rat immunoglobulins; RAM, rat anti-mouse immunoglobulins; rIgE, rat IgE.

J. Clin. Invest.

(C) The American Society for Clinical Investigation, Inc.

0021-9738/95/02/0577/09 \$2.00

Volume 95, February 1995, 577-585
IgE-binding $\alpha$ subunit, associated with a four-transmembrane domain $\beta$ subunit and a homodimeric $\gamma$ subunit (2). A consensus tyrosine-containing activation motif, in intracytoplasmic (IC) domains of $\mathrm{Fc} \epsilon \mathrm{RI} \beta$ and $\gamma$ (3), is thought to account for the cell-activating properties of Fc $\epsilon$ RI (4).

Mast cells $(5,6)$ and basophils $(7,8)$ also express lowaffinity $\mathrm{IgG}$ receptors $(\mathrm{Fc} \gamma \mathrm{R})$. Depending on their subtype, mouse mast cells express Fc $\gamma$ RII and Fc $\gamma$ RIII in variable proportions (6). Fc $\gamma$ RIII are multichain-receptors composed of a IgG-binding $\alpha$ subunit (9), associated in mast cells with the same $\beta$ (10) and $\gamma(11)$ subunits as $\mathrm{Fc} \in \mathrm{RI} \alpha$. When aggregated by multivalent IgG immune complexes, Fc $\gamma$ RIII also trigger the release of inflammatory mediators (12) and cytokines (13). Under the same conditions, Fc $\gamma$ RII do not $(12,13)$. Fc $\gamma$ RII are single-chain receptors which exist as two isoforms generated by alternative splicing of sequences of the first IC exon, Fc $\gamma$ RIIb1 and Fc $\gamma$ RIIb2, which differ by a 47-amino acid insertion in the IC domain of Fc $\gamma$ RIIb1 (9). Human basophils express Fc $\gamma$ RII (8), but no Fc $\gamma$ RIII, and they failed to release histamine when challenged with anti-Fc $\gamma$ RII (C. Lawrence and M. Daëron, unpublished data). Ancient experiments aiming at demonstrating the ability of IgG immune complexes to trigger histamine release in human basophils were contradictory $(14,15)$. Human Fc $\gamma$ RII are of two types: Fc $\gamma$ RIIA/C and Fc $\gamma$ RIIB. Fc $\gamma$ RIIA/C are single-chain receptors the IC domain of which possesses a tyrosine-containing activation motif (9) with cell-triggering capability (16). Fc $\gamma$ RIIB resemble closely murine Fc $\gamma$ RII and they share a common IC aminoacid sequence (9).

Evidence that FcR aggregation is a necessary and sufficient signal for triggering a cellular response (17-20) was based on studies using multivalent ligands specific of a single FcR. Most cells, however, express several types of $\mathrm{FcR}$ and antibodies of more than one isotype are usually produced together against a given antigen. When antigen reaches Fc $\epsilon$ RI-bound IgE antibodies on mast cells, it is therefore probably complexed to IgG antibodies, if IgG antibodies were generated against the same antigen. This is likely to occur during immunotherapy in allergic patients, when high titers of anti-allergen IgG antibodies have been raised (21), but also during a normal immune response. Under these conditions, Fc $\epsilon \mathrm{RI}$ are therefore not only aggregated, they are also cross-linked to adjacent $\mathrm{Fc} \gamma \mathrm{R}$. In the present work, we examined the consequences of cross-linking Fce RI to Fc $\gamma$ RII on IgE-induced mast cell activation.

We found that, when cross-linked to FceRI, both Fc $\gamma$ RII isoforms inhibit mediator and cytokine release triggered by Fc $\epsilon$ RI aggregation and that inhibition depends on Fc $\gamma$ RII intracytoplasmic sequences common to Fc $\gamma$ RIIb1 and b2. We showed that inhibition requires Fc $\epsilon$ RI-Fc $\gamma$ RII cross-linking, affects only crosslinked Fc $\epsilon$ RI and is reversible. Our results provide a new hypothesis for the development of allergic manifestations and offer a possible mechanism for desensitization in 
allergic patients. Because mediator release could be abrogated in mast cells previously sensitized with $\mathrm{IgE}$, they suggest new therapeutic approaches of allergic diseases.

\section{Methods}

Antibodies, antibody fragments, and antigens. The rat monoclonal IgE LO-DNP-30 and IR 162 were from IMEX (Université de Louvain, Bruxelles, Belgium). The mouse IgE anti-DNP 2682-I mAb was a gift of Dr. Ulrich Blank (Institut Pasteur, Paris). It was purified from culture supernatant of a subclone of DNP-H1- $\epsilon-26$ hybridoma cells (22). The mouse IgE $14.205 \mathrm{~A} 1 \mathrm{mAb}(23)$ was purified by immunoaffinity chromatography from ascitic fluid, generously offered by Dr. Colette Kanellopoulos (Institut Jacques Monod, Paris). IgE-rich anti-ovalbulin serum raised in the Copacabana strain of Swiss mice was kindly provided by Dr. Annie Prouvost-Danon (Fundação Oswaldo Cruz, Rio de Janeiro, Brazil). Rat and mouse IgE bound equally well to rat and mouse mast cell Fc $\in$ RI. Mouse IgG1 anti-DNP mAb, purified on Protein G-sepharose, was a gift of Dr. Jacques Couderc (Institut Curie, Paris). Unlabeled and FITC-labeled polyclonal mouse anti-rat Ig (MAR) F(ab')2 fragments, as well as rat anti-mouse Ig (RAM) $F\left(a b^{\prime}\right) 2$ fragments were from Jackson Immunoresearch Laboratories (West Grove, PA). MAR $\mathrm{F}\left(\mathrm{ab}^{\prime}\right) 2$ reacted with rat Ig, but not with mouse Ig, and RAM $\mathrm{F}\left(\mathrm{ab}^{\prime}\right) 2$ reacted with mouse Ig, but not with rat Ig. This was checked both by indirect immunofluorescence and by serotonin release on RBL cells sensitized with mouse and rat IgE respectively. The anti-Fc $\gamma \mathrm{RII} / \mathrm{III}$ $2.4 \mathrm{G} 2 \mathrm{mAb}(24)$ was purified by affinity-chromatography on Protein $\mathrm{G}$-sepharose from ascitic fluid of nude mice inoculated with 2.4G2 hybridoma cells intraperitoneally. $F\left(a b^{\prime}\right) 2$ fragments were obtained by pepsin digestion for $48 \mathrm{~h}$. The purity of $2.4 \mathrm{G} 2 \mathrm{IgG}$ and $\mathrm{F}\left(\mathrm{ab}^{\prime}\right) 2$ fragments was assessed by SDS-PAGE analysis. $2.4 \mathrm{G} 2$ reacted with mouse $\mathrm{Fc} \gamma \mathrm{R}$, but not with rat $\mathrm{Fc} \gamma \mathrm{R}$.

Heteroconjugates made by chemically crosslinking Fab fragments of 2.4G2 and affinity-purified rabbit polyclonal anti-DNP antibodies (referred to as [2.4G2 $\times$ a-DNP] Fab2) were described previously (25). (2.4G2 $\times$ a-DNP) Fab2 bind to Fc $\gamma$ RII via the $2.4 \mathrm{G} 2$ Fab moiety and to dinitrophenyl conjugates via the anti-DNP Fab moiety. They were a generous gift of Dr. David M. Segal (NIH, Bethesda, MD).

Mouse IgE 14.205 A1, BSA (Sigma Chemical Co., St. Louis, MO) and ovalbumin (Sigma Chemical Co.) were dinitrophenylated using 2-,4-dinitrobenzene sulfonic acid (Eastman Kodak Co., Rochester, NY). After passage over Sephadex G25 (Pharmacia, Uppsala, Sweden), the average substitution numbers of dinitrophenylated proteins were 7.5 moles DNP/mole IgE, 13 moles DNP/mole BSA and 4 moles DNP/ mole ovalbumin. Rat IgE IR162 was biotinylated using the kit from Sigma Chemical Co. Streptavidin was from Pierce (Rockford, IL), Llysine and N- $\epsilon$-DNP-L-lysine from Sigma Chemical Co.

Cells. BMMC were prepared from BALB/c bone marrow cells as described (26). They were maintained in culture in RPMI medium (Seromed, Biochrom A. G., Berlin, Germany) supplemented with $10 \%$ FCS, $100 \mathrm{IU} / \mathrm{ml}$ penicillin, $100 \mu \mathrm{g} / \mathrm{ml}$ streptomycin, and $50 \%$ conditioned medium from WEHI-3 cells. P815 mouse mastocytoma cells and L929 cells were cultured in RPMI supplemented with $10 \%$ FCS, 100 $\mathrm{IU} / \mathrm{ml}$ penicillin and $100 \mu \mathrm{g} / \mathrm{ml}$ streptomycin. RBL-2H3 cells (27) were cultured in DMEM supplemented with $10 \% \mathrm{FCS}, 100 \mathrm{IU} / \mathrm{ml}$ penicillin and $100 \mu \mathrm{g} / \mathrm{ml}$ streptomycin. Only adherent RBL cells were used. They were recovered with trypsin-EDTA. Except RPMI, all culture reagents were from GIBCO BRL (Paisley, Scotland, UK).

Immunoprecipitation of iodine-labeled mast cells. BMMC or P815 cells were ${ }^{125}$ I-labeled using lactoperoxydase. Membrane $\mathrm{Fc} \gamma \mathrm{R}$ were precipitated with $2.4 \mathrm{G} 2$ and analyzed by SDS-PAGE under reducing conditions, before and after endoglycosidase-F (Bohringer Biochimica, Mannheim, Germany) treatment as previously described (6).

cDNA constructions and transfectants. RBL-2H3 cells stably transfected with cDNAs encoding murine Fc $\gamma$ RIIb1 (28) and Fc $\gamma$ RIIb2 (29), IC domain-deleted Fc $\gamma$ RIIb2 (IC1) (30), or chimeric Fc $\gamma$ RIIICIII $\alpha$ (12) were described previously (12). All transfectants used were cloned as described (12). They were maintained in culture in the presence of $250 \mu \mathrm{g} / \mathrm{ml} \mathrm{G} 418$ (Geneticin; GIBCO BRL) and the expression of recombinant receptors on clones remained stable over the duration of experiments.

Immunofluorescence. Nontransfected and transfected RBL-2H3 cells were incubated for $1 \mathrm{~h}$ at $0^{\circ} \mathrm{C}$ with $10 \mu \mathrm{g} / \mathrm{ml}$ rat monoclonal IgE LODNP-30 or $2.4 \mathrm{G} 2 \mathrm{mAb}$ in HBSS containing $5 \%$ FCS, or with medium alone. Cells were washed and stained by being incubated for $30 \mathrm{~min}$ at $0^{\circ} \mathrm{C}$ with $50 \mu \mathrm{g} / \mathrm{ml}$ FITC-labeled MAR $\mathrm{F}\left(\mathrm{ab}^{\prime}\right) 2$. Fluorescence was analyzed by flow cytometry using a FACScan (Becton-Dickinson, Mountain View, CA).

Serotonin release. Transfected or nontransfected RBL-2H3 cells, resuspended in RPMI medium supplemented with $10 \%$ FCS at $1 \times 10^{6}$ cells $/ \mathrm{ml}$, were incubated at $37^{\circ} \mathrm{C}$ for $1 \mathrm{~h}$. with $2 \mu \mathrm{Ci} / \mathrm{ml}\left[{ }^{3} \mathrm{H}\right]$ serotonin (Amersham, Les Ulis, France), washed, resuspended in RPMI-FCS, incubated for another hour at $37^{\circ} \mathrm{C}$, washed again, resuspended in the same medium and distributed in 96-well microculture plates at $2 \times 10^{5}$ cells/well and incubated for $1 \mathrm{~h}$ at $37^{\circ} \mathrm{C}$ with $\operatorname{IgE}$ in a final volume of $50 \mu \mathrm{l}$. Adherent cells were washed four times with $200 \mu \mathrm{l}$ HBSS (GIBCO BRL), $25 \mu \mathrm{l}$ culture medium were added to each well and cells were warmed at $37^{\circ} \mathrm{C}$ for $15 \mathrm{~min}$ before challenge. Cells were challenged for $30 \mathrm{~min}$ at $37^{\circ} \mathrm{C}$ with $25 \mu \mathrm{l}$ of MAR $\mathrm{F}\left(\mathrm{ab}^{\prime}\right) 2$, RAM $\mathrm{F}\left(\mathrm{ab}^{\prime}\right)$ 2, DNP-BSA or streptavidin, previously warmed at $37^{\circ} \mathrm{C}$ for 15 min. Reactions were stopped by adding $50 \mu$ ice-cold medium and by placing plates on ice. $50 \mu$ l of supernatants were mixed with $200 \mu$ l Aqualuma-Plus scintillation fluid (Lumac, The Netherlands) and counted in a $\beta$-plate counter (Pharmacia, Uppsala, Sweden). The percentage of serotonin release was calculated using as $100 \% \mathrm{cpm}$ contained in $50 \mu \mathrm{l}$ harvested from wells containing the same number of cells that were lysed in $100 \mu \mathrm{l}$ of $0.5 \%$ SDS and $0.5 \%$ NP40.

BMMC were sensitized by an overnight incubation at $37^{\circ} \mathrm{C}$ with IgErich anti-ovalbumin immune serum before being loaded with $\left[{ }^{3} \mathrm{H}\right]$ serotonin under the same conditions as RBL cells. After washings and warming, cells were challenged for $10 \mathrm{~min}$ at $37^{\circ} \mathrm{C}$ with DNP-ovalbumin in Eppendorf tubes.

TNF release and assay. Aliquots of $7 \times 10^{5} \mathrm{RBL}$ cells, previously sensitized by a $1-\mathrm{h}$ incubation at $37^{\circ} \mathrm{C}$ with indicated concentrations of IgE, were resuspended in $150 \mu \mathrm{l}$ culture medium and incubated for 3 $\mathrm{h}$ at $37^{\circ} \mathrm{C}$ with $50 \mu \mathrm{g} / \mathrm{ml}$ MAR F( $\left.\mathrm{ab}^{\prime}\right) 2$ fragments. Cell-free supernatants were harvested and assayed for TNF $\alpha$. TNF $\alpha$ was measured by a cytotoxic assay on the TNF $\alpha$-sensitive L929 cells as described (13). Briefly, $3 \times 10^{4}$ L929 cells were plated in each well of 96-well tissue culture plates. After a 20 -h incubation at $37^{\circ} \mathrm{C}$, culture medium was replaced by serial twofold dilutions of cell-free supernatants from stimulated cells. Supernatants were diluted in complete medium containing $1.5 \mu \mathrm{g} / \mathrm{ml}$ actinomycin $\mathrm{D}$ (Boehringer). After a 20 -h incubation at $37^{\circ} \mathrm{C}$, medium was removed, adherent cells were stained with $0.2 \%$ crystalviolet (Sigma Chemical Co.) in $1 \%$ ethanol for $15 \mathrm{~min}$, wells were washed, dried, and the absorbance was measured at $570 \mathrm{~nm}$ using a Titerteck spectrophotometer (Labsystems, Helsinki, Finland).

\section{Results}

Inhibition of IgE-induced secretory responses by complexation of antigen to IgG antibodies in Fc $\gamma$ RII-expressing mast cells. Bone marrow-derived mast cells (BMMC), sensitized with polyclonal IgE anti-ovalbumin (ova), released serotonin upon challenge with DNP-ova (Fig. $1 a$ ). Nonsensitized BMMC did not release serotonin when challenged with DNP-ova or with DNP-ova complexed to monoclonal IgG1 anti-DNP (Fig. 1 $a$, open circles). DNP-ova-induced IgE-dependent serotonin release was found to decrease progressively if DNP-ova was complexed to increasing concentrations of IgG1 anti-DNP (Fig. 1 a, closed symbols). Inhibition was also observed when DNPova was complexed with dilutions of ascitic fluid of the same IgGl anti-DNP hybridoma (not shown). The same was ob- 

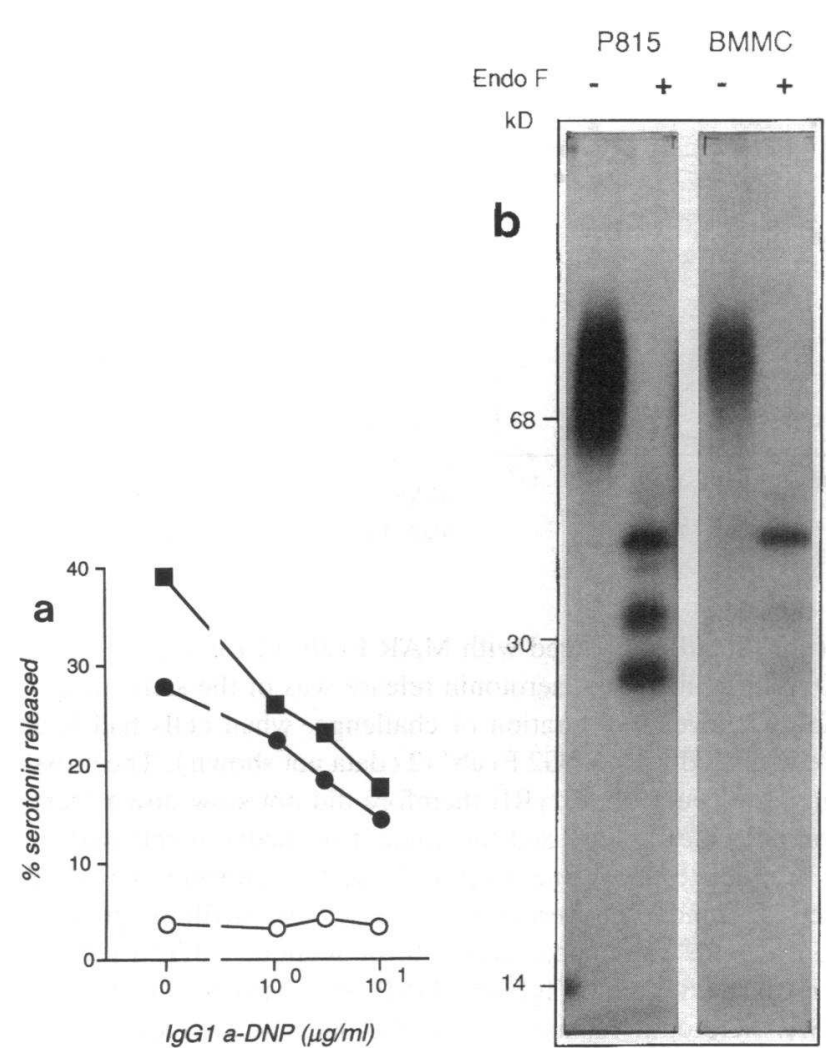

Figure 1. Inhibition of IgE-induced bone marrow-derived mast cell (BMMC) activation by IgG immune complexes and $\mathrm{Fc} \gamma \mathrm{R}$ expressed by BMMC. (a) BMMC were sensitized or not with polyclonal mouse IgE anti-ova by an overnight incubation at $37^{\circ} \mathrm{C}$ with IgE-rich antiovalbumin serum diluted $1 / 1000$ (squares) or $1 / 3000$ (closed circles), or with culture medium only (open circles). Cells were challenged for $10 \mathrm{~min}$ at $37^{\circ} \mathrm{C}$ with $20 \mu \mathrm{g} / \mathrm{ml}$ DNP-ova, not complexed, or complexed with indicated concentrations of purified IgG1 anti-DNP mAb. The figure shows the percentage of total radioactivity released in supernatants. (b) Membrane Fc $\gamma \mathrm{R}$ were precipitated from ${ }^{125} \mathrm{I}$-labeled BMMC and P815 cells with 2.4G2 and examined by SDS-PAGE under reducing conditions, before and after deglycosylation with endoglycosidase $F$.

served in three other experiments of the same design, on BMMC sensitized with monoclonal IgE anti-DNP and challenged with DNP-BSA complexed to IgG1 anti-DNP (not shown). Antigen complexation to IgG antibodies therefore decreased IgE-mediated serotonin release by mouse mast cells.

Low-affinity IgG receptors expressed by BMMC were immunoprecipitated by the rat anti-mouse Fc $\gamma$ RII/III mAb 2.4G2 and examined by SDS-PAGE analysis before and after endoglycosidase-F treatment. Deglycosylated polypeptides with an apparent m.w. of 37,32 , and $28 \mathrm{kD}$ were precipitated from the control mouse mastocytoma cells P815. They were previously identified as Fc $\gamma \mathrm{RIIb} 1, \mathrm{Fc} \gamma \mathrm{RIIb} 2$, and $\mathrm{Fc} \gamma \mathrm{RIII} \alpha$ respectively $(6,31)$. Confirming our previous results $(6)$, large amounts of Fc $\gamma$ RIIb1 were precipitated from BMMC, but only traces of Fc $\gamma$ RIIb2 and Fc $\gamma$ RIII $\alpha$ (Fig. $1 b$ ). These results altogether raised the possibility that the crosslinking of Fc $\gamma$ RIIb1 to Fc $\in$ RI by immune complexes could inhibit IgE-induced mast cell activation and the subsequent secretory response.

Inhibition of IgE-induced secretory responses by cross-linking FceRI and FcyRII in RBL-2H3 transfectants. The latter hypothesis was tested using Rat Basophilic Leukemia cells a

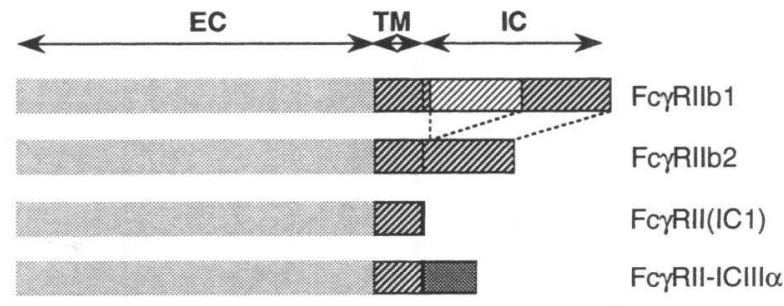

b
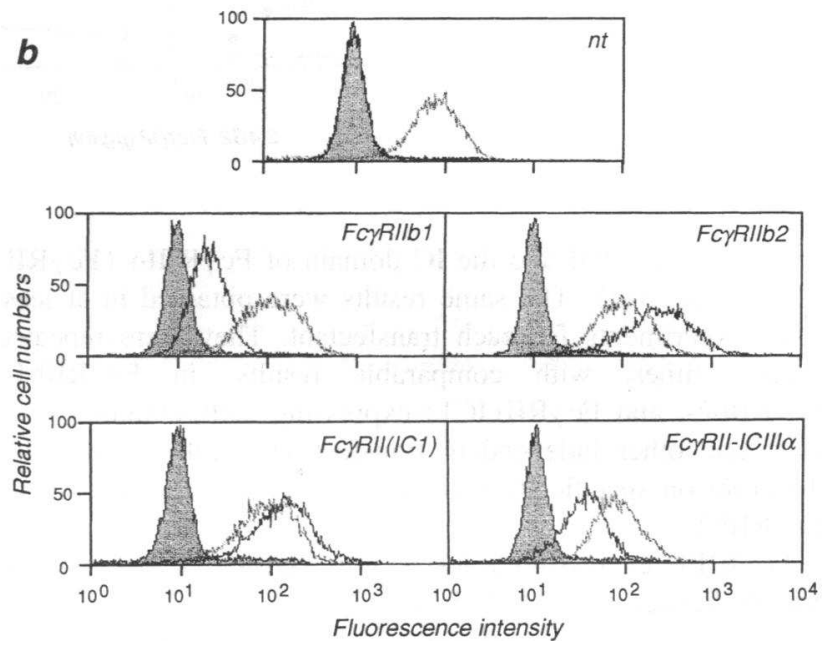

Figure 2. Structure and expression of wild-type and mutant murine Fc $\gamma$ RII in RBL-2H3 cells. ( $a$ ) The figure schematizes the structure of recombinant murine Fc $\gamma$ RIIb1, Fc $\gamma$ RIIb2, IC domain-deleted Fc $\gamma$ RII (IC1), or chimeric Fc $\gamma$ RII-ICIII $\alpha$ encoded by the cDNAs transfected into RBL-2H3 cells. EC, extracellular; TM, transmembrane; and IC, intracytoplasmic domains. ( $b$ ) Clones of stable transfectants were examined by immunofluorescence for the expression of $\mathrm{Fc} \in \mathrm{RI}$ and murine $\mathrm{Fc} \gamma \mathrm{R}$. The binding of the rat monoclonal IgE LO-DNP-30 (open gray histograms) and of 2.4G2 (open black histograms) to nontransfected RBL-2H3 cells (nt) and to RBL-2H3 cells transfected with cDNA encoding wild-type Fc $\gamma \mathrm{RIIb} 1$ and Fc $\gamma \mathrm{RIIb} 2$, deleted Fc $\gamma \mathrm{RII}(\mathrm{IC} 1)$ or chimeric Fc $\gamma$ RII-ICIII $\alpha$ was examined by indirect immunofluorescence with FITC-labeled (MAR) F(ab')2. Shaded histograms represent the fluorescence of cells incubated with FITC-MAR $F\left(a b^{\prime}\right) 2$ only.

(RBL-2H3) stably transfected with cDNAs encoding wild-type, deleted or chimeric murine Fc $\gamma$ RII (Fig. $2 a$ ). The surface expression of murine Fc $\gamma \mathrm{RII}$ and of endogenous $\mathrm{Fc} \in \mathrm{RI}$ was assessed by indirect immunofluorescence with $2.4 \mathrm{G} 2$ and with rat monoclonal IgE respectively (Fig. $2 b$ ). The expression of Fc $\gamma$ RII was checked again, systematically, in all subsequent experiments. When sensitized with rat IgE, all transfectants released serotonin upon challenge with $\mathrm{MAR} F\left(\mathrm{ab}^{\prime}\right) 2$ (Fig. 3 ). When preincubated with $2.4 \mathrm{G} 2 \mathrm{~F}\left(\mathrm{ab}^{\prime}\right) 2$ fragments, no transfectant released serotonin above background upon challenge with MAR $F\left(a b^{\prime}\right) 2$ (Fig. 3, open circles). The effect of cross-linking $F c \gamma$ RII to $F c \in R I$ was searched for by studying serotonin release triggered by MAR $F\left(\mathrm{ab}^{\prime}\right) 2$ in RBL transfectants sensitized with rat IgE, and incubated with increasing concentrations of $\mathrm{F}\left(\mathrm{ab}^{\prime}\right) 2$ fragments of the rat mAb 2.4G2 (Fig. 3, closed symbols). IgE-induced serotonin release was inhibited by crosslinking FceRI to Fc $\gamma$ RIIb1 (Fig. $3 a$ ) or Fc $\gamma$ RIIb2 (Fig. $3 b$ ), but not to Fc $\gamma$ RII deleted of all but one intracytoplasmic aminoacids (Fc $\gamma$ RII [IC1], Fig. $3 c$ ) or to chimeric receptors having the extracellular and transmembrane 


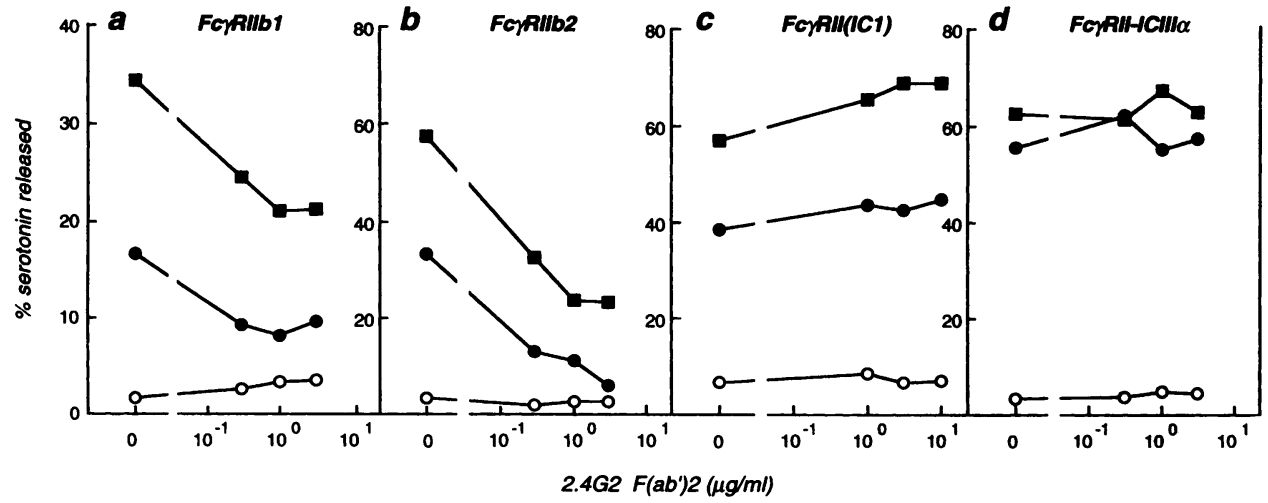

Figure 3. Inhibition of IgE-induced serotonin release by wild-type Fc $\gamma$ RII in RBL transfectants. RBL transfectants expressing wild-type Fc $\gamma$ RIIb1 (a) or Fc $\gamma \mathrm{RIIb} 2(b)$, deleted Fc $\gamma \mathrm{RII}-$ (IC1) (c) or chimeric Fc $\gamma$ RIII-ICIII $\alpha$ (d) were incubated for $1 \mathrm{~h}$ at $37^{\circ} \mathrm{C}$ with 0 (open circles), 0.1 (closed circles), or 0.3 (squares) $\mu \mathrm{g} / \mathrm{ml}$ rat IgE LO-DNP-30 and with indicated concentrations of $2.4 \mathrm{G} 2 \mathrm{~F}\left(\mathrm{ab}^{\prime}\right) 2$. After being washed, cells were challenged for $30 \mathrm{~min}$ at $37^{\circ} \mathrm{C}$ with $50 \mu \mathrm{g} / \mathrm{ml}$ MAR F $\left(\mathrm{ab}^{\prime}\right) 2$, and serotonin released in supernatants was measured. domains of Fc $\gamma$ RII and the IC domain of Fc $\gamma$ RIII $\alpha$ (Fc $\gamma$ RIIICIII $\alpha$, Fig. $3 d$ ). The same results were obtained in at least three experiments for each transfectant. They were repeated several times, with comparable results, in Fc $\gamma$ RIIb1-, Fc $\gamma$ RIIb2-, and Fc $\gamma$ RII(IC1)-expressing cells obtained in at least one other independent transfection. Inhibition depends therefore on specific IC sequences common to Fc $\gamma \mathrm{RIIb} 1$ and Fc $\gamma$ RIIb2.

Fc $\gamma$ RIIb2-expressing transfectants, sensitized with rat $\operatorname{IgE}$ and challenged with MAR $\mathrm{F}\left(\mathrm{ab}^{\prime}\right) 2$ for $3 \mathrm{~h}$ at $37^{\circ} \mathrm{C}$, produced TNF $\alpha$ that could be quantitated by assaying cytotoxicity of cellfree supernatants on L929 cells. Cytotoxicity depended on the concentration of IgE used for sensitization (Fig. 4, open circles). It was markedly reduced if cells were incubated with 2.4G2 F( $\left.\mathrm{ab}^{\prime}\right) 2$ before challenge with MAR F( $\left.\mathrm{ab}^{\prime}\right) 2$ (Fig. 4, closed symbols $)$. Like inhibition of serotonin release, inhibition of TNF production was proportional to the dilution of IgE used for sensitization. IgE-induced mediator release and cytokine production were therefore both inhibited by crosslinking Fc $\epsilon$ RI to Fc $\gamma$ RII.

Inhibition of IgE-induced mediator release requires $F c \in R I-$ Fc $\gamma R I I$ cross-linking. In order to determine whether the decreased serotonin release might result from a change in the kinetics of the release process, Fc $\gamma$ RIIb2-expressing cells were sensitized with rat IgE in the presence or absence of $2.4 \mathrm{G} 2$
$\mathrm{F}\left(\mathrm{ab} \mathrm{b}^{\prime}\right) 2$ and challenged with MAR $\mathrm{F}\left(\mathrm{ab} \mathrm{b}^{\prime}\right) 2$ for $15,30,45$, or $60 \mathrm{~min}$. Inhibition of serotonin release was of the same magnitude whatever the duration of challenge, when cells had been preincubated with 2.4G2 F( $\left.\mathrm{ab}^{\prime}\right) 2$ (data not shown). The crosslinking of $F c \in R I$ to Fc $\gamma$ RII therefore did not slow down secretion but indeed decreased the amount of mediator released.

In order to determine whether Fc $\gamma$ RII occupancy would affect IgE-induced serotonin release, Fc $\gamma$ RIIb2-expressing transfectants were incubated with or without $2.4 \mathrm{G} 2 \mathrm{~F}\left(\mathrm{ab}^{\prime}\right) 2$, sensitized with mouse IgE anti-DNP, and challenged with DNPBSA. Serotonin release was of the same magnitude in cells preincubated or not with $2.4 \mathrm{G} 2 \mathrm{~F}\left(\mathrm{ab}^{\prime}\right) 2$ (data not shown). Ligand binding to Fc $\gamma$ RII (binding of 2.4G2 was checked by indirect immunofluorescence) therefore had no inhibitory effect. To determine whether an independent Fc $\gamma$ RII aggregation would affect IgE-induced serotonin release, Fc $\gamma$ RIIb2-expressing transfectants were incubated with $2.4 \mathrm{G} 2 \mathrm{~F}\left(\mathrm{ab}^{\prime}\right) 2$ and sensitized with mouse IgE anti-DNP. They were washed, preincubated for various periods of time at $37^{\circ} \mathrm{C}$ with $\mathrm{MAR} F\left(\mathrm{ab}^{\prime}\right) 2$, and finally challenged with DNP-BSA (Fig. 5). Compared to cells not preincubated with MAR F( $\left.\mathrm{ab}^{\prime}\right) 2$ (open symbols), serotonin release induced by DNP-BSA was unaffected in the presence of MAR $F\left(a b^{\prime}\right) 2$, whatever the duration of the preincubation with MAR $\mathrm{F}\left(\mathrm{ab}^{\prime}\right) 2$ (closed symbols). The aggregation of Fc $\gamma$ RII therefore had no effect on IgE-induced serotonin
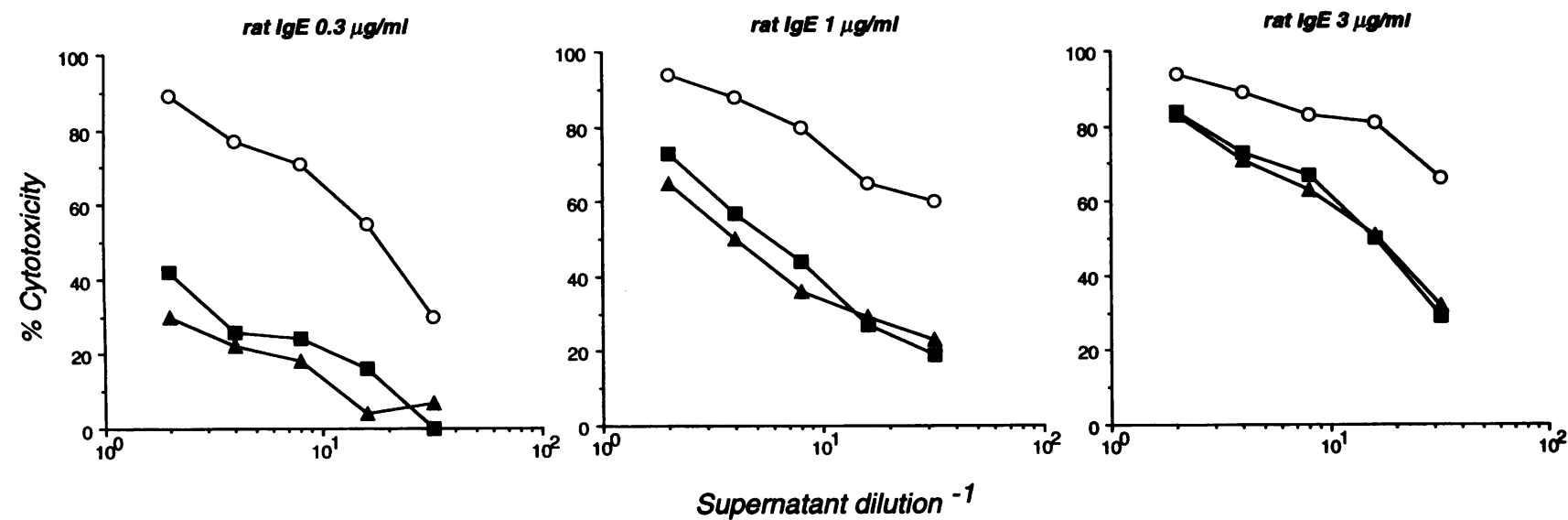

Figure 4. Inhibition of IgE-induced TNF $\alpha$ production by RBL transfectants expressing Fc $\gamma$ RIIIb2. Fc $\gamma$ RIIb2-expressing transfectants were sensitized with $0.3,1$, or $3 \mu \mathrm{g} / \mathrm{ml}$ rat IgE LO-DNP-30, in the presence of 0 (open circles), 1 (closed squares), or 10 (closed triangles) $\mu \mathrm{g} / \mathrm{ml} 2.4 \mathrm{G} 2 \mathrm{~F}(\mathrm{ab}$ ') 2 . They were challenged with $50 \mu \mathrm{g} / \mathrm{ml}$ MAR F $\left(\mathrm{ab}^{\prime}\right) 2$ for $3 \mathrm{~h}$ at $37^{\circ} \mathrm{C}$. Cell-free supernatants were harvested and twofold dilutions were tested for cytotoxicity on $\mathrm{L} 929$ cells. The figure represents the percentage of cytotoxicity as a function of the dilution of supernatants. 


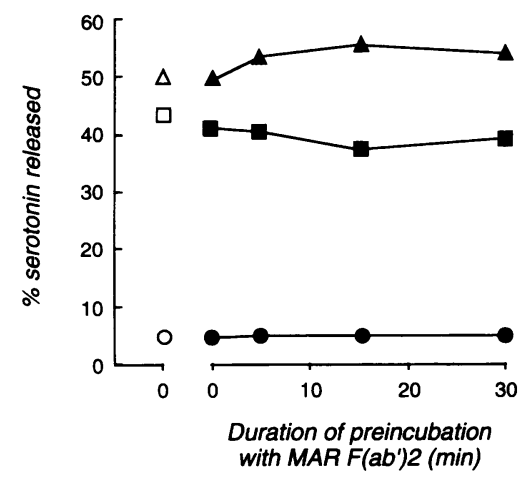

Figure 5. Crosslinking requirement for Fc $\gamma$ RIIb2-mediated inhibition of IgE-induced serotonin release. Fc $\gamma$ RIIb2-expressing transfectants were sensitized with 0 (circles), 0.03 (squares), or 0.1 (triangles) $\mu \mathrm{g} / \mathrm{ml}$ mouse IgE anti-DNP 2682-I in the presence of $3 \mu \mathrm{g} / \mathrm{ml}$ 2.4G2 F(ab')2. Cells were then preincubated with 0 (open symbols) or 50 (closed symbols) $\mu \mathrm{g} / \mathrm{ml}$ MAR F( $\left.\mathrm{ab}^{\prime}\right) 2$ for indicated times at $37^{\circ} \mathrm{C}$ before they were washed and challenged with $3 \mu \mathrm{g} / \mathrm{ml}$ DNP-BSA for $30 \mathrm{~min}$.

release, even if achieved $30 \mathrm{~min}$ before challenge with antigen. No effect on IgE-induced serotonin release was seen following an independent $\mathrm{Fc} \gamma \mathrm{RII}$ aggregation in two other experiments.

In above experiments, Fc $\epsilon$ RI were cross-linked to Fc $\gamma$ RII by the same reagent that was used also for challenge (DNP-BSA or MAR $F\left[a b^{\prime}\right] 2$, depending on the IgE). Under these conditions, Fc $\epsilon$ RI-Fc $\gamma$ RII cross-linking and Fc $\epsilon$ RI aggregation were simultaneous. To dissociate the two events, Fc $\gamma$ RIIb2-expressing transfectants were sensitized with a dinitrophenylated mouse monoclonal IgE, not directed against DNP, 14.205 A1, (DNPmIgE) that could be subsequently cross-linked to Fc $\gamma$ RII with heteroaggregates made of $2.4 \mathrm{G} 2$ Fab fragments and rabbit antiDNP Fab fragments (referred to as [2.4G2 $\times$ a-DNP] Fab2), without being aggregated. Cells were then challenged with rat anti-mouse Ig (RAM) F( $\left.a^{\prime}{ }^{\prime}\right) 2$ to aggregate $F c \in R I$. Serotonin release induced by RAM F ( $\left.\mathrm{ab}^{\prime}\right) 2$ was abolished, whatever the concentration of DNP-mIgE used for sensitization, if cells were preincubated with as little as $0.3 \mu \mathrm{g} / \mathrm{ml}(2.4 \mathrm{G} 2 \times \mathrm{a}-\mathrm{DNP}) \mathrm{Fab} 2$ (Fig. $6 a$ ).

Nontransfected cells and transfectants expressing Fc $\gamma$ RIIb1 or Fc $\gamma$ RII(IC1 ) were sensitized by the same DNP-mIgE, incubated with or without $(2.4 \mathrm{G} 2 \times$ a-DNP) Fab2, and challenged with RAM $F\left(a b^{\prime}\right) 2$. When not exposed to $(2.4 \mathrm{G} 2 \times$ a-DNP) Fab2, all three cells released serotonin upon challenge. Serotonin release was abolished if Fc $\gamma$ RIIb1-expressing transfectants, but not $\mathrm{Fc} \gamma \mathrm{RII}$ (IC1)-expressing transfectants or nontransfected cells, were preincubated with $(2.4 \mathrm{G} 2 \times$ a-DNP $)$ Fab2. Under the same conditions, $(2.4 \mathrm{G} 2 \times$ a-DNP $)$ Fab2 did not inhibit serotonin release by Fc $\gamma$ RIIb1-expressing transfectants sensitized with the same IgE, but not dinitrophenylated (Fig. $6 b$ ). Identical results were seen in at least three experiments of the same design performed with each transfectant. Fc $\epsilon$ RI-Fc $\gamma$ RII crosslinking, prior to Fc $\epsilon$ RI aggregation, therefore abrogated subsequent serotonin release.

Inhibition reversibly affects only FcєRI cross-linked to $F c \gamma R I I$. The possibility to dissociate Fc $\epsilon$ RI-Fc $\gamma$ RII crosslinking from $F c \in R I$ aggregation enabled to examine whether inhibition would affect only crosslinked Fc $\epsilon$ RI or whether it would affect also other $\mathrm{Fc} \in \mathrm{RI}$. This was achieved by sensitizing mast cells with two types of IgE which could be cross-linked to Fc $\gamma$ RII or aggregated independently. When sensitized with dinitrophenylated mouse IgE 14.205 A1 (DNP-mIgE), Fc $\gamma$ RIIb2-expressing transfectants released serotonin upon challenge with RAM F (ab')2 (Fig. 7 a, open circles), but not with streptavidin (not shown). Serotonin release was inhibited if cells were preincubated with (2.4G2 $\times$ a-DNP) Fab2 (Fig. 7 a, closed circles). When sensitized with biotinylated rat IgE IR162 (Biot-rIgE), Fc $\gamma$ RIIb2-expressing transfectants released serotonin upon challenge with streptavidin (Fig. $7 \mathrm{~b}$, open circles), but not with RAM $F\left(a b^{\prime}\right) 2$ (not shown). Serotonin release was not affected if cells were preincubated with $(2.4 \mathrm{G} 2 \times$ a-DNP) Fab2 (Fig. $7 \mathrm{~b}$, closed circles). When sensitized with a mixture of DNP-mIgE and Biot-rIgE, Fc $\gamma$ RIIb2-expressing transfectants released serotonin upon challenge with either RAM F(ab')2 or streptavidin, and a dose-dependent competition between the two IgE used for sensitization could be seen (Fig. $7 c-f$, open circles). Serotonin release induced by RAM F(ab') 2 (Fig. 7 $c$ and $e$, closed circles), but not serotonin release induced by streptavidin (Fig. $7 d$, and f, closed circles), was abolished if cells were incubated with $(2.4 \mathrm{G} 2 \times$ a-DNP) Fab2 prior to challenge. It follows that inhibition was restricted to FceRI crosslinked to Fc $\gamma$ RII and left non-cross-linked Fc $\epsilon$ RI fully capable of triggering mediator release upon aggregation. The same conclusion could be drawn from two additional experiments of the same design performed with the same reagents.

Finally, we wondered whether inhibition observed upon Fc $\epsilon$ RI-Fc $\gamma$ RII cross-linking would be reversed upon crosslinking disengagement in the presence of an excess of monovalent hapten. Fc $\gamma$ RIIb2-expressing transfectants were sensitized with dinitrophenylated mouse IgE 14.205 A1 (DNP-mIgE) that was subsequently cross-linked or not cross-linked to Fc $\gamma$ RIIb2 with (2.4G2 $\times$ a-DNP) Fab2, as in above experiments. Cells were then incubated for increasing periods of time at $37^{\circ} \mathrm{C}$ with an excess of DNP-lysine or, as a negative control, of lysine, before they were challenged with RAM $F\left(a b^{\prime}\right) 2$. As expected, serotonin release was inhibited when cells not exposed to hapten were incubated with $(2.4 \mathrm{G} 2 \times$ a-DNP) Fab2 (Fig. 8, open circles). DNP-lysine (black circles) had no effect on serotonin release induced by the aggregation of DNP-mIgE not crosslinked to Fc $\gamma$ RIIb2 (broken line), but it reduced by $50 \%$ inhibition of serotonin release induced by aggregating DNP-mIgE crosslinked to Fc $\gamma$ RIIb2 (solid line). The same molar concentration of lysine (grey circles) had no effect on inhibition (solid line). Comparable results were obtained in two other experiments. This indicates that $\mathrm{Fc} \epsilon \mathrm{RI}$ whose triggering ability was previously abolished recovered from inhibition upon cross-linking disengagement. Inhibition therefore is reversible and requires that $\mathrm{Fc} \in \mathrm{RI}-\mathrm{Fc} \gamma \mathrm{RII}$ cross-linking be maintained.

\section{Discussion}

Our results demonstrate that mast cell activation via high-affinity receptors for IgE may be controlled by low-affinity receptors for IgG. This control was effective whenever Fc $\epsilon$ RI were crosslinked to Fc $\gamma$ RII with an intact IC domain, irrespectively of the cross-linking ligand. It required $\mathrm{F} c \epsilon \mathrm{RI}-\mathrm{Fc} \gamma \mathrm{RII}$ cross-linking, affected only Fc $\epsilon$ RI crosslinked to Fc $\gamma$ RII and was reversible upon cross-linking disengagement. Such a regulation might be of physiological and of clinical relevance.

Inhibition was observed in RBL transfectants, when endogeneous rat $\mathrm{F} c \epsilon \mathrm{RI}$ were cross-linked to recombinant murine Fc $\gamma$ RIIb1 or to Fc $\gamma$ RIIb2. Inhibition was not due to a competition between IgE and 2.4G2 for MAR F ( $\left.a b^{\prime}\right) 2$ or to extracellular steric hindrance for the following two reasons: $(a)$ the MAR $\mathrm{F}\left(\mathrm{ab}^{\prime}\right) 2$ concentration used for crosslinking IgE and 2.4G2 $\mathrm{F}\left(\mathrm{ab}^{\prime}\right) 2$ was 25 -fold higher than the concentration sufficient 


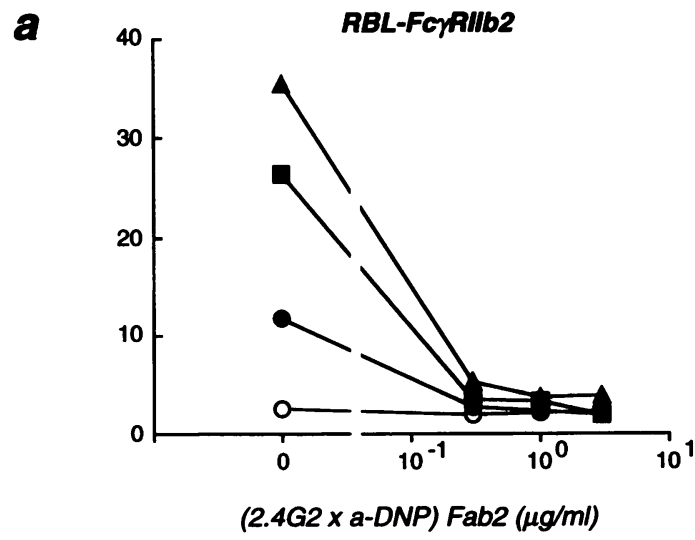

$\boldsymbol{b}$

RBL-FCYAIIb1

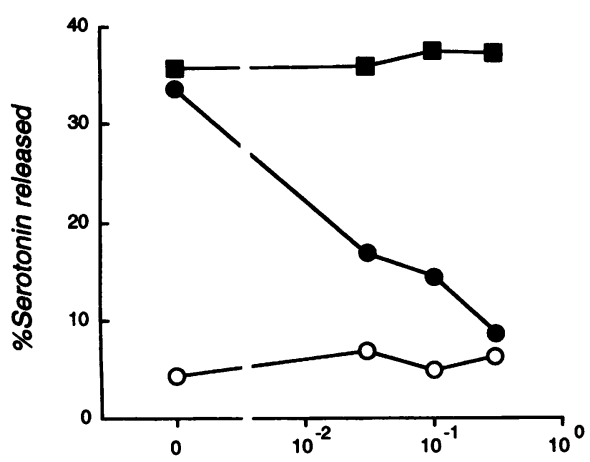

RBL-FCYRIIIC1)

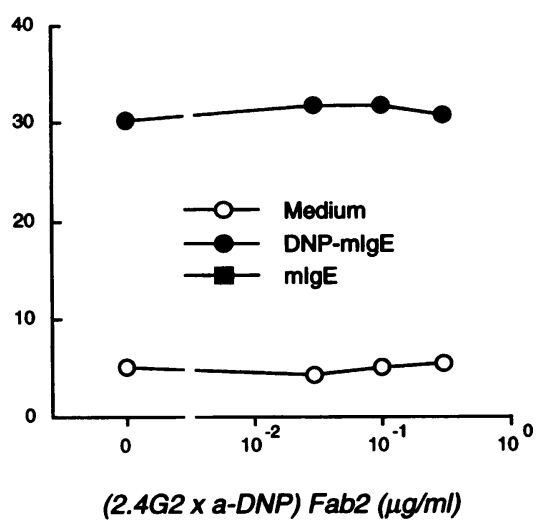

RBL-2H3

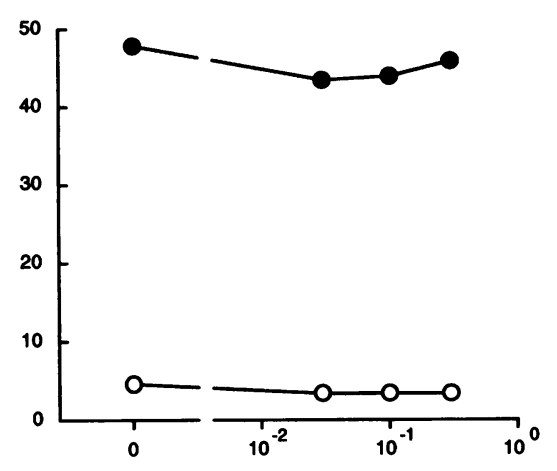

Figure 6. Inhibition of IgE-induced serotonin release by cross-linking Fc $\in \mathrm{RI}$ to Fc $\gamma \mathrm{RII}$ before challenge. (a) Fc $\gamma \mathrm{RIIb} 2$-expressing transfectants were sensitized with 0 (open circles), 1 (closed circles), 3 (closed squares), or 10 (closed triangles) $\mu \mathrm{g} / \mathrm{ml}$ dinitrophenylated mouse IgE 14.205 $\mathrm{A} 1$ (DNP-mIgE). After being washed, cells were incubated for $1 \mathrm{~h}$ at $37^{\circ} \mathrm{C}$ with indicated concentrations of $(2.4 \mathrm{G} 2 \times$ a-DNP) Fab2, washed again,

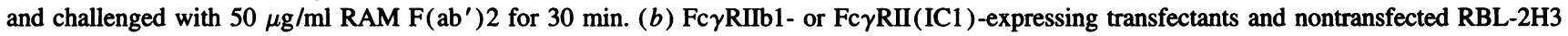
cells were sensitized with 0 (open circles) or $3 \mu \mathrm{g} / \mathrm{ml}$ IgE $14.205 \mathrm{A1}$, dinitrophenylated (DNP-mIgE, closed circles) or not (mIgE, closed squares). After being washed, cells were incubated for $1 \mathrm{~h}$ at $37^{\circ} \mathrm{C}$ with indicated concentrations of (2.4G2 $\times$ a-DNP) Fab2, washed again, and challenged with $50 \mu \mathrm{g} / \mathrm{ml} \mathrm{RAM} \mathrm{F}\left(\mathrm{ab}^{\prime}\right) 2$ for $30 \mathrm{~min}$.

for triggering an optimal serotonin release upon aggregation of IgE, and comparable inhibitions were seen when 50,25 or $12.5 \mu \mathrm{g} / \mathrm{ml}$ MAR $\mathrm{F}\left(\mathrm{ab}^{\prime}\right) 2$ were used for challenge (data not shown); (b) Inhibition was not seen in cells expressing Fc $\gamma$ RII deletants lacking IC domain, which bound comparable amounts of $2.4 \mathrm{G} 2 \mathrm{~F}\left(\mathrm{ab}^{\prime}\right) 2$ fragments as wild-type Fc $\gamma \mathrm{RII}$ as judged by immunofluorescence with FITC-conjugated MAR F(ab')2. Steric hindrance of IC domains could neither account for inhibition because it was not seen in transfectants expressing chimeric receptors having the extracellular and transmembrane domains of Fc $\gamma$ RII and the IC domain of Fc $\gamma$ RIII $\alpha$. Inhibition therefore depends on specific IC sequences shared by Fc $\gamma$ RIIbl and Fc $\gamma$ RIIb2. Murine Fc $\gamma$ RII have been known for long to inhibit $B$ cell activation triggered by $B$ cell receptor (BCR) aggregation, and IC sequences required for Fc $\gamma$ RII to inhibit BCRmediated B cell activation have recently been identified (32, 33). Whether the same Fc $\gamma$ RII IC sequences are responsible for Fc $\gamma$ RII-mediated inhibition of IgE-induced mast cell activation is currently under study. BCR, like Fc $\epsilon$ RI and Fc $\gamma$ RIII, is composed of a ligand-binding subunit, associated with two subunits whose IC domains possess consensus tyrosine-con- taining activation motifs similar to those of FceRI $\gamma$ and $\beta$ (34), and it may be a general property of Fc $\gamma$ RII to regulate tyrosinecontaining activation motif-dependent cell activation.

Inhibition affected secretory responses of mast cells as different as the release of preformed mediators and the de novo synthesis of cytokines. It is therefore susceptible to control both the initiation of allergic reactions and the late phase reaction in which cytokines play a major role (35). Inhibition, however was not the consequence of a general desensitization of mast cells since non-cross-linked receptors could function normally and triggered serotonin release upon aggregation while crosslinked receptors could not. Inhibition was not an all-or-nothing phenomenon. Experiments on Fc $\gamma$ RIIb2-expressing transfectants incubated with lower concentrations of 2.4G2 F(ab')2 than those used in Fig. 3 showed a clearcut dose-dependent inhibition (not shown). Inhibition required the crosslinking of Fc $\epsilon$ RI to Fc $\gamma$ RII. MAR F ( $\left.\mathrm{ab}^{\prime}\right) 2$ could indeed crosslink rat IgE LO-DNP-30 and rat 2.4G2 $\mathrm{F}\left(\mathrm{ab}^{\prime}\right) 2$ inasmuch as $(a)$ the same MAR F $\left(a^{\prime}\right) 2$ conjugated to FITC bound to both rat reagents in indirect immunofluorescence experiments (see Fig. 2), and (b) MAR $\mathrm{F}\left(\mathrm{ab}^{\prime}\right) 2$ were functionally divalent since they trig- 
Challenge: RAM F(ab')2

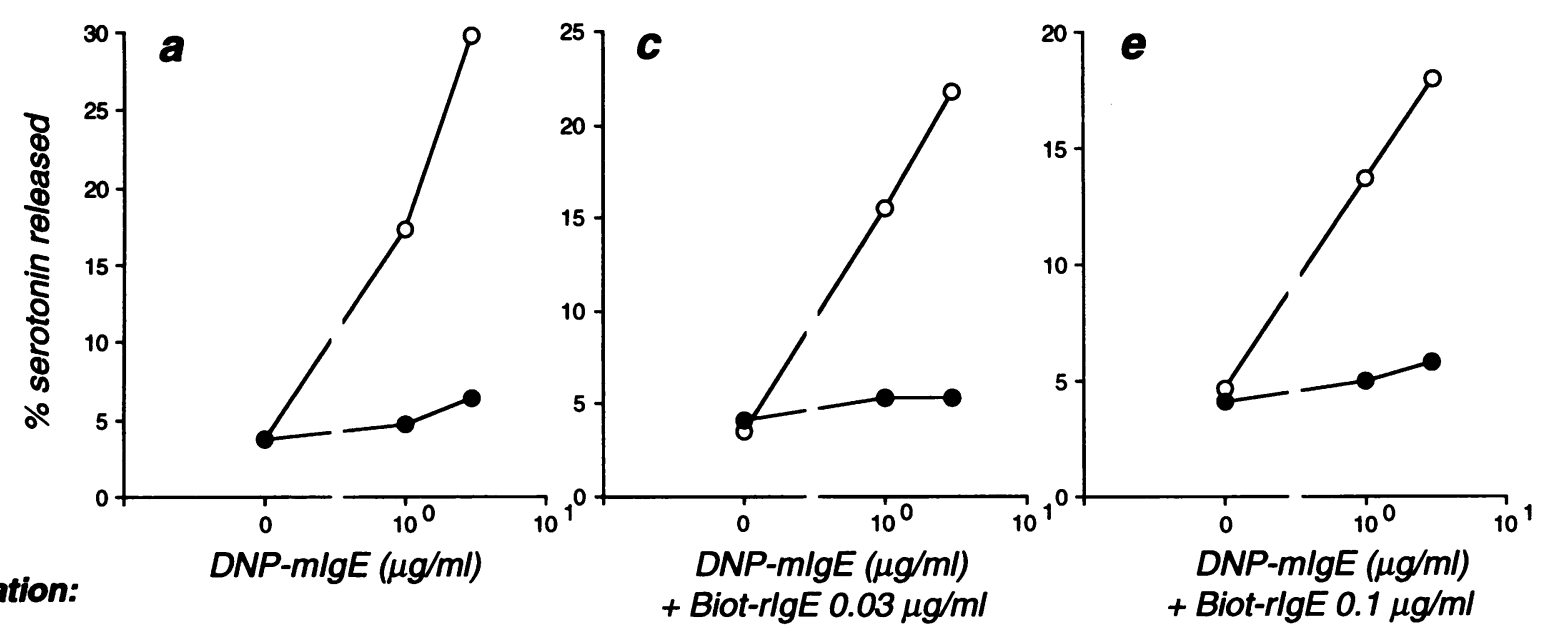

Sensitization:

+ Biot-rlgE $0.03 \mu g / m l$

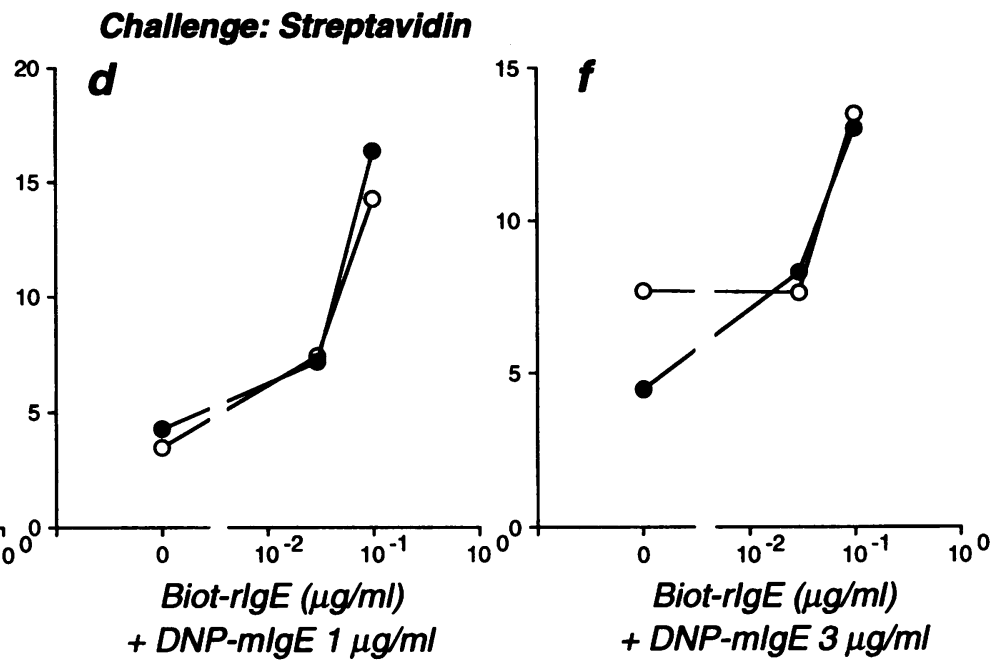

Sensitization:

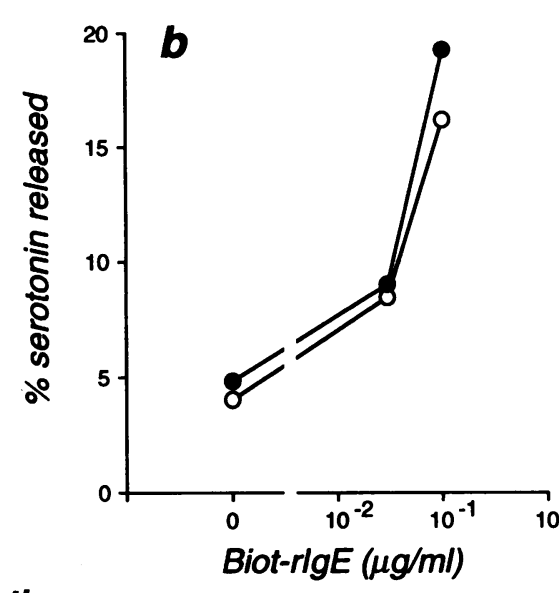

Figure 7. Inhibition of IgE-induced serotonin release affects only Fc $\epsilon$ RI crosslinked to Fc $\gamma$ RII. Fc $\gamma$ RIIb2-expressing transfectants were sensitized with dinitrophenylated mouse IgE 14.205 A1 (DNP-mIgE) and/or biotinylated rat IgE IR162 (Biot-rIgE) at concentrations indicated in abscissa, and preincubated for $1 \mathrm{~h}$ at $37^{\circ} \mathrm{C}$ with (closed circles) or without (open circles) $1 \mu \mathrm{g} / \mathrm{ml}(2.4 \mathrm{G} 2 \times \mathrm{a}$-DNP) Fab2. Cells were washed and challenged

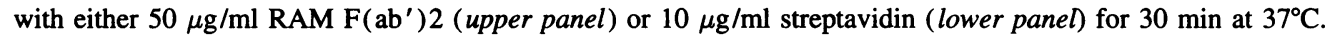

gered serotonin release and TNF secretion by RBL cells sensitized with rat IgE (this manuscript) and by transfectants expressing Fc $\gamma$ RIII preincubated with $2.4 \mathrm{G} 2 \mathrm{~F}\left(\mathrm{ab}^{\prime}\right) 2(12,13)$. Neither Fc $\gamma$ RII occupancy by $2.4 \mathrm{G} 2 \mathrm{~F}\left(\mathrm{ab}^{\prime}\right) 2$ nor Fc $\gamma$ RII aggregation by $2.4 \mathrm{G} 2 \mathrm{~F}\left(\mathrm{ab}^{\prime}\right) 2$ and $\operatorname{MAR} \mathrm{F}\left(\mathrm{ab}^{\prime}\right) 2$, by themselves, affected serotonin release. This was confirmed with $(2.4 \mathrm{G} 2 \times \mathrm{a}$ DNP) Fab2 which had no effect when bound only to Fc $\gamma$ RII (in Fc $\gamma$ RIIb1-expressing cells sensitized with nondinitrophenylated $\operatorname{IgE}$ ), or to IgE only (in nontransfected cells sensitized with DNP-IgE), but abolished serotonin release when cross-linking IgE to Fc $\gamma$ RII with an intact IC domain (in Fc $\gamma$ RIIb1- and Fc $\gamma$ RIIb2-, but not in Fc $\gamma$ RII(IC1)-expressing cells, sensitized with DNP-IgE). Moreover, inhibition could be reversed when DNP-mIgE previously cross-linked to Fc $\gamma$ RII by $(2.4 \mathrm{G} 2 \times$ aDNP) Fab2 were disengaged from cross-linking with monovalent DNP-Lysine. One may notice that a prolonged exposure to DNP-Lysine was required for inhibition to be reduced. Whether this reflects a low dissociation rate of multiple interactions between (2.4G2 $\times$ a-DNP) Fab2 and DNP $_{7.5}-$ mIgE or whether Fc $\epsilon$ RI required time to recover from cross-linking is not known. We are currently investigating the intracellular consequences of receptor cross-linking.

Inhibition was not seen only in RBL transfectants, when recombinant murine Fc $\gamma$ RII were artificially cross-linked to rat Fc $\epsilon$ RI with monoclonal anti-Fc $\gamma R$ antibodies and MAR $\mathrm{F}\left(\mathrm{ab}^{\prime}\right) 2$ or with $(2.4 \mathrm{G} 2 \times \mathrm{a}-\mathrm{DNP}) \mathrm{Fab} 2$ heteroaggregates. IgEinduced serotonin release was also inhibited in nontransformed mast cells, which express constitutive Fc $\gamma$ RII, sensitized with polyclonal serum IgE, when receptor cross-linking was achieved by IgG immune complexes. To rule out a possible competition of antibodies for the same epitope, we used IgE and IgG antibodies of different specificities. The complexation of DNP-BSA to IgG1 anti-DNP mAb also inhibited the release of serotonin by BMMC sensitized with mouse monoclonal IgE 


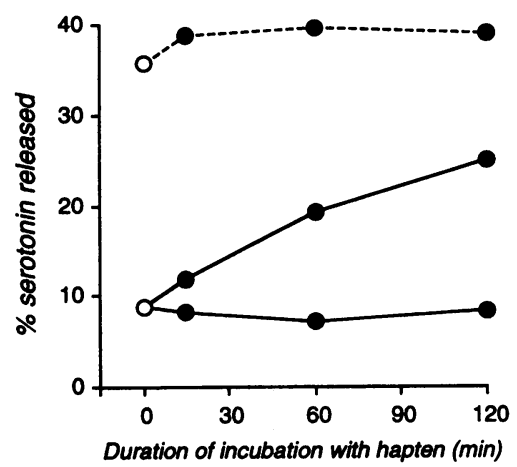

Figure 8. Reversal of inhibition of IgE-induced serotonin release upon disengagement of Fc $\in$ RI-Fc $\gamma$ RII crosslinking. Fc $\gamma$ RIIb2-expressing transfectants were sensitized with 10 $\mu \mathrm{g} / \mathrm{ml}$ dinitrophenylated mouse IgE $14.205 \mathrm{~A} 1$, washed, and preincubated with (solid lines) or without (broken line) $1 \mu \mathrm{g} / \mathrm{ml}(2.4 \mathrm{G} 2 \times \mathrm{a}-$

DNP) Fab2 for $1 \mathrm{~h}$ at $37^{\circ} \mathrm{C}$. They were washed and incubated at $37^{\circ} \mathrm{C}$ for indicated periods of time with $100 \mu \mathrm{M}$ DNP-Lysine (black circles) or lysine ( gray circles), added at various times (all cells were incubated for a total of $2 \mathrm{~h}$ ). Cells were washed and challenged with $50 \mu \mathrm{g} / \mathrm{ml}$ $\operatorname{RAM} \mathrm{F}\left(\mathrm{ab}^{\prime}\right) 2$ for $30 \mathrm{~min}$ at $37^{\circ} \mathrm{C}$

anti-DNP, as well as the production of TNF $\alpha$ by the murine mastocytoma cells MC9 sensitized with IgE anti-DNP (data not shown). Under these conditions, competition between IgG and IgE antibodies for the same epitopes cannot be excluded. An inhibitory effect of Fc $\gamma$ RII, rather than a competition for antigen or an extracellular steric hindrance, however, was strongly suggested by the finding that inhibition of the TNF response was abolished if MC9 cells were preincubated with with $2.4 \mathrm{G} 2$ $\mathrm{F}\left(\mathrm{ab}^{\prime}\right) 2$ before challenge with immune complexes (data not shown). 2.4G2 $\mathrm{F}\left(\mathrm{ab}^{\prime}\right) 2$, indeed, block the Fc-binding site of Fc $\gamma$ RII (24). Immune complex-induced inhibition mimics physiologic conditions, when IgG antibodies directed against identical or different epitopes of the same antigen as IgE antibodies interact with Fc $\gamma \mathrm{RII}$ by their Fc portions, while antigen binds Fc $\epsilon$ RI-bound IgE on the same cell. A reasonable hypothesis would be that, during the course of a normal immune response, physiologic IgE-mediated mast cell activation might occur in the presence of antigen, which would be normally maintained at low levels by IgG antibodies bound to the same antigen, so that no sign of hypersensitivity is detectable. If so, one can speculate that allergic manifestations might arise when, for any reason, this control is not efficient enough.

This also reminds the situation when allergic patients are treated by the injection of increasing amounts of allergen. Such an immunotherapy is usually successful after high titers of IgG antibodies have been induced against allergen (21), but no satisfactory mechanism was yet proposed. Human Fc $\gamma$ RIIB are the human equivalent of murine Fc $\gamma \mathrm{RII}$, and they were recently reported to inhibit murine $B$ cell activation (36). One might therefore expect that Fc $\gamma$ RIIB could be capable of regulating Fc $\epsilon$ RI in human basophils. If so, inhibition described here might not only explain the success of desensitization, it might also explain its relative inefficacy. When Fc $\epsilon$ RI aggregation and crosslinking to Fc $\gamma$ RII were simultaneously produced by MAR $F\left(a b^{\prime}\right) 2$ reacting with $F c \gamma$ RII-bound $2.4 G 2 F\left(a b^{\prime}\right) 2$ and Fc $\epsilon$ RI-bound rat IgE, or by antigen-IgG immune complexes, inhibition was partial and inversely proportional to the concentration of IgE used for sensitization. Under these conditions, one cannot prevent adjacent IgE molecules from being aggregated without being cross-linked to 2.4G2, and chances of IgE aggregation can be expected to increase with the density of IgE at the cell surface.
It was recently reported that asthmatic patients injected with IgG immune complexes made with allergen and affinity-purified anti-allergen IgG antibodies had markedly reduced symptoms $(37,38)$. The mechanism of this effect was not investigated and we propose the inhibition described here as a likely explanation. This suggests that manoeuvres aiming at crosslinking Fc $\epsilon$ RI to Fc $\gamma$ RII might be successful for controlling hypersensitivity manifestations in allergic patients. One advantage of Fc $\gamma$ RII-mediated inhibition of IgE-induced mast cell activation, in terms of therapeutics, is that it can operate after mast cells were already sensitized with IgE, as it is the case in allergic patients. Our model where DNP-IgE are crosslinked to Fc $\gamma$ RII by $(2.4 \mathrm{G} 2 \times$ a-DNP) Fab2, simulates such a therapeutic approach. Under these conditions, the inhibitory effect was deep enough for enabling less than $1 \mu \mathrm{g} / \mathrm{ml}(2.4 \mathrm{G} 2 \times \mathrm{a}-\mathrm{DNP}) \mathrm{Fab} 2$ to abolish serotonin release triggered by $50 \mu \mathrm{g} / \mathrm{ml}$ MAR $\mathrm{F}\left(\mathrm{ab}^{\prime}\right) 2$ in $\mathrm{RBL}$ cells sensitized with $10 \mu \mathrm{g} / \mathrm{ml}$ IgE. The higher efficacy of bispecific heteroaggregates in inhibiting IgE-induced serotonin release, compared with that of $2.4 \mathrm{G} 2 \mathrm{~F}\left(\mathrm{ab}^{\prime}\right) 2$ and MAR F $\left(a b^{\prime}\right) 2$, may be explained because the preincubation of transfectants with $(2.4 \mathrm{G} 2 \times$ a-DNP) Fab2 enabled Fc $\epsilon$ RI to be cross-linked to Fc $\gamma$ RII before Fc $\epsilon$ RI-bound IgE were aggregated by RAM F $\left(a b^{\prime}\right) 2$. Appropriate ligands capable to reproduce the same cross-linking in humans are currently under investigation.

\section{Acknowledgments}

We are grateful to: Drs. P. M. Hogarth (Melbourne University, Parkville, Victoria), J. V. Ravetch (Memorial Sloan Kettering Cancer Center, New York, NY) and I. Mellman (Yale University School of Medicine, New Haven, CT) for their generous gifts of cDNAs, to Dr. J. Kanellopoulos (Institut Pasteur, Paris) for RBL-2H3 cells, to Dr. D. M. Segal (NIH, Bethesda, MD) for (2.4G2 $\times$ a-DNP) Fab2, and to Drs. U. Blank (Institut Pasteur, Paris), A. Prouvost-Danon (Fundação Oswaldo Cruz, Rio de Janeiro), J. Couderc (Institut Curie, Paris), and C. Kanellopoulos (Institut Jacques Monod, Paris) for antibodies. We acknowledge the expert technical assistance of Ms. Fabienne Vozy, Annie Galinha, Marie-Annick Provost-Marloie and Geneviève Averlant.

This work was supported in part by the INSERM, Roussel-UCLAF and the Institut Curie.

\section{References}

1. Kinet, J.-P., and H. Metzger. 1990. Genes, structure, and actions of the high-affinity Fc receptor for immunoglobulin E. In Fc Receptors and the Action of Antibodies. H. Metzger, editor. American Society for Microbiology, Washington. 239-259.

2. Blank, U., C. Ra, L. Miller, K. White, H. Metzger, and J.-P. Kinet. 1989. Complete structure and expression in transfected cells of high affinity IgE receptor. Nature (Lond.). 337:187-190.

3. Reth, M. G. 1989. Antigen receptor tail clue. Nature (Lond.). 338:383384.

4. Paolini, R., M. H. Jouvin, and J.-P. Kinet. 1991. Phosphorylation and dephosphorylation of the high-affinity receptor for immunoglobulin E immediately after receptor engagement and disengagement. Nature (Lond.). 353:855-858.

5. Tigelaar, R. E., N. M. Vaz, and Z. Ovary. 1971. Immunoglobulin receptors on mouse mast cells. J. Immunol. 106:661-670.

6. Benhamou, M., C. Bonnerot, W. H. Fridman, and M. Daëron. 1990. Molecular heterogeneity of murine mast cell Fc $\gamma$ receptors. J. Immunol. 144:3071 -3077.

7. Ishizaka, T., A. R. Sterk, and K. Ishizaka. 1979. Demonstration of Fc receptors on human basophil granulocytes. J. Immunol. 123:138-142.

8. Anselmino, L. M., B. Perussia, and L. L. Thomas. 1989. Human basophils selectively express the Fc $\gamma$ RII (CDw32) subtype of IgG receptor. J. Allergy Clin. Immunol. 84:907-914.

9. Ravetch, J. V., and J.-P. Kinet. 1991. Fc receptors. Annu. Rev. Immunol. 9:457-492.

10. Kurosaki, T., I. Gander, U. Wirthmueller, and J. V. Ravetch. 1992. The 
$\beta$ subunit of the $\mathrm{Fc} \in \mathrm{RI}$ is associated with the Fc $\gamma \mathrm{RIII}$ on mast cells. J. Exp. Med. 175:447-451.

11. Ra, C., M. H. E. Jouvin, U. Blank, and J.-P. Kinet. 1989. A macrophage Fc $\gamma$ receptor and the mast cell receptor for IgE share an identical subunit. Nature (Lond.). 341:752-754.

12. Daëron, M., C. Bonnerot, S. Latour, and W. H. Fridman. 1992. Murine recombinant $\mathrm{Fc} \gamma \mathrm{RIII}$, but not $\mathrm{Fc} \gamma \mathrm{RII}$, trigger serotonin release in rat basophilic leukemia cells. J. Immunol. 149:1365-1373.

13. Latour, S., C. Bonnerot, W. H. Fridman, and M. Daëron. 1992. Induction of tumor necrosis factor- $\alpha$ production by mast cells via Fc $\gamma \mathrm{R}$. Role of the Fc $\gamma$ RIII $\gamma$ subunit. J. Immunol. 149:2155-2162.

14. Vigay, H. M., and L. Perelmutter. 1977. Inhibition of reagin-mediated PCA reactions in monkeys and histamine release from human leukocytes by IgG4 subclass. Int. Arch. Allergy Appl. Immunol. 53:78-87.

15. Van Toorenenbergen, A. W., and R. C. Aalberse. 1981. IgG4 and passive sensitization of basophil leukocytes. Int. Arch. Allergy Appl. Immunol. 65:432440 .

16. Kolanus, W., C. Romeo, and B. Seed. 1992. Lineage-independent activation of immune system effector function by myeloid Fc receptors. EMBO (Eur. Mol. Biol. Organ.) J. 11:4861-4869.

17. Ovary, Z. 1961. Activité des substances à faible poids moléculaire dans les réactions antigène-anticorps in vivo et in vitro. C. $R$. Acad. Sci. (Paris). 253:582-583.

18. Segal, D. M., J. D. Taurog, and H. Metzger. 1977. Dimeric immunoglobulin E serves as a unit signal for mast cell degranulation. Proc. Natl. Acad. Sci. USA. 74:2993-2997.

19. Ishizaka, T., and $K$. Ishizaka. 1978. Triggering of histamine from rat mast cells by divalent antibodies against IgE receptor. J. Immunol. 120:800-806.

20. Metzger, H. 1992. Transmembrane signaling: the joy of aggregation. $J$. Immunol. 149:1477-1487.

21. Gleich, G. J., E. M. Zimmermann, L. L. Henderson, and J. W. Yunginger. 1978. Effect of immunotherapy on immunoglobulin $E$ and immunoglobulin $G$ antibodies to ragweed antigens: a six-year prospective study. J. Allergy Clin. Immunol. 62:261-270.

22. Liu, T. T., J. W. Bohn, E. L. Ferry, H. Yamamoto, and C. A. Molinaro. 1980. Monoclonal dinitrophenyl-specific murine IgE antibody. Preparation, isolation and characterization. J. Immunol. 124:2728-2735.

23. Böttcher, I., G. Hämmerling, and J. F. Kapp. 1978. Continous production of monoclonal mouse IgE antibodies with known allergenic specificity by a hybrid cell line. Nature (Lond.). 275:761-762.

24. Unkeless, J. C. 1979. Characterization of monoclonal antibody directed against mouse macrophage and lymphocyte Fc receptors. J. Exp. Med. 150:580596.

25. Daëron, M., O. Malbec, S. Latour, S. Bonnerot, D. M. Segal, and W. H. Fridman. 1993. Distinct intracytoplasmic sequences are required for endocytosis and phagocytosis via murine Fc $\gamma$ RII in mast cells. Intern. Immunol. 5:13931401.

26. Lanotte, M., M. Arock, N. Lacaze, and D. Guy-Grand. 1986. Murine basophil-mast differentiation: toward optimal conditions for selective growth and maturation of basophil-mast or allied cells. J. Cell. Physiol. 129:199-206.

27. Barsumian, E. L., C. Isersky, M. G. Petrino, and R. P. Siraganian. 1981. IgE-induced histamine release from rat basophilic leukemia cell lines: isolation of releasing and nonreleasing clones. Eur. J. Immunol. 11:317-321.

28. Hibbs, M. L., I. D. Walker, L. Kirszbaum, G. A. Pietersz, N. J. Deacon, G. W. Chambers, I. F. C. McKenzie, and P. M. Hogarth. 1986. The murine Fc receptor for immunoglobulin: purification, partial amino acid sequence, and isolation of cDNA clones. Proc. Natl. Acad. Sci. USA. 83:6980-6984.

29. Ravetch, J. V., A. D. Luster, R. Weinshank, J. Kochan, A. Pavlovec, D. A. Portnoy, J. Hulmes, Y. C. E. Pan, and J. C. Unkeless. 1986. Structural heterogeneity and functional domains of murine immunoglobulin G Fc receptors. Science (Wash. DC). 234:718-725.

30. Miettinen, H. M., J. K. Rose, and I. Mellman. 1989. Fc receptor isoforms exhibit distinct abilities for coated pit localization as a result of cytoplasmic domain heterogeneity. Cell. 58:317-327.

31. Daëron, M., C. Bonnerot, S. Latour, M. Benhamou, and W. H. Fridman. 1990. The murine $\alpha \mathrm{Fc} \gamma \mathrm{R}$ gene product: identification, expression and regulation. Mol. Immunol. 27:1181-1188.

32. Amigorena, S., C. Bonnerot, J. Drake, D. Choquet, W. Hunziker, J. G. Guillet, P. Webster, C. Sautès, I. Mellman, and W. H. Fridman. 1992. Cytoplasmic domain heterogeneity and functions of IgG Fc receptors in B-lymphocytes. Science (Wash. DC). 256:1808-1812.

33. Muta, T., T. Kurosaki, Z. Misulovin, M. Sanchez, M. C. Nussenzweig, and J. V. Ravetch. 1994. A 13-amino-acid motif in the cytoplasmic domain of Fc $\gamma$ RIIB modulates B-cell receptor signalling. Nature (Lond.). 368:70-73.

34. Clark, M. R., K. S. Campbell, A. Kazlauskas, S. A. Johnson, M. Hertz, T. A. Potter, C. Pleiman, and J. C. Cambier. 1992. The B cell antigen receptor complex: association of $\operatorname{Ig} \alpha$ and $\operatorname{Ig} \beta$ with distinct cytoplasmic effectors. Science (Wash. DC). 258:123-126.

35. Charlesworth, E. N., O. Illiopoulos, S. M. MacDonald, A. Kagey-Sobotka, and L. M. Lichtenstein. 1989. Cells and secretagogues involved in the human late-phase response. Int. Arch. Allergy Appl. Immunol. 88:50-57.

36. Van den Herik-Oudijk, I. E., N. A. C. Westerdaal, N. V. Henriquez, P. J. A. Capel, and J. G. J. Van de Winkel. 1994. Functional analysis of human Fc $\gamma$ RII (CD32) isoforms expressed in B lymphocytes. J. Immunol. 152:574585

37. Machiels, J. J., M. A. Somville, M. G. Jacquemin, and J. M. R. Saint-Rémy. 1991. Allergen-antibody complexes can efficiently prevent seasonal rhinitis and asthma in grass pollen hypersensitive patients. Allergy. 46:335-348.

38. Machiels, J. J., P. M. Lebrun, M. G. Jacquemin, and J. M. R. Saint-Rémy. 1993. Significant reduction of nonspecific bronchial reactivity in patients with Dermatophagoides pteronyssinus-sensitive allergic asthma under therapy with allergen-antibody complexes. Am. Rev. Respir. Dis. 147:1407-1412. 